\title{
Students' Need Analysis on Prose Studies Course in English Literature
}

\author{
Fety Surfaifel*, Yanty Wirza
}

\author{
English Education Department, Universitas Pendidikan Indonesia \\ *Corresponding author. Email: fetysurfaifel@upi.edu
}

\begin{abstract}
Need analysis is the opening stage in program scheme and provision rationality and relevance and those after that program activity in architecture. This study aims to describe the students' need for a Prose Studies course in the English Literature Study Program Universitas Flores. The approach used in this analysis is a method of development (Research and development / R \& D). This study rests on efforts to produce and validate an educational product. The gathering data technique is the essential phase in the analysis since the primary principle is to get the data. For compiling the data, the researcher uses the questionnaire as the instrument. It was distributed to thirty respondents via WAG; twenty-five of them send it back. Thus, it was calculated and analysed qualitatively. After performing data analysis, researchers conclude that student needs at Semester V Prose Studies course for the English Literature Study Program, Universitas Flores, namely: Prose teaching material is integrated with English skills: speaking, reading, listening, and writing. The teaching methods respondents need when studying processes are in groups, workshops/performance, study in pairs, and study alone. The topics favoured by respondents in the learning process are theory under the scientific discipline, contextual material, science and technology, and material about daily activities.
\end{abstract}

Keywords: Need analysis, prose, textbook

\section{INTRODUCTION}

In the old paradigm, language learning is carried out with a uniform (unitary) approach. In this approach, learners are given the same linguistic presentation. Language learning programs are designed to be applied to all learners, regardless of their communication goals. The uniform approach received criticism from the communicative approach. According to the communicative approach, the content of language learning should reflect the purposes of the learners. Education is designed to be tailored to learners' needs, not learners adjusting to the learning design

According to Richterich and Chancerel (in Modi \& Patel, 2018), the students are at the core of everything, and everything begins and finishes with them. In other terms, everything applies exclusively to them. The students are the instruments for determining their learning targets, selecting the strategies for measuring the time and how they have been accomplished, and making a program accessible to them. Also, Richterich and Chancerel (in Modi \& Patel, 2018) suggest some aspects that need to be implemented following the student approach into the structure built. They are opportunities for students to contribute, debate, compromise, and engage in concentrating their learning on the students themselves while staying within an institutional context. Education as a method of schooling must be socially significant. Also, Allo (2018) suggests that the needs analysis flow can guide the designer. Courses to provide clear and precise definitions of course content for certain groups of learners.

Needs analysis is the starting point for the course design. In this study, a needs analysis was carried out in the Prose Studies course. This subject is taught in the fifth semester at Universitas Flores, English Literature Study Program. The Prose Studies course's general objective is that after the end of learning this subject, students are expected to produce one work in the form of Prose Fiction of a short story. The teacher must consider several aspects of the learning process. These things elaborate and accomplish the specific objectives of each material sub-topic, teaching and learning activities (teaching activities and student activities), 
selecting media and teaching tools, teaching strategies, and evaluating learning.

Furthermore, Richards (2001) agrees that needs analysis should involve learners, teachers, administrators, and executors of the planning process to identify language-specific needs and language program content. Besides, it is necessary to evaluate ongoing programs. So far, research has emphasized the importance of needs analysis for planning courses, writing textbooks, or teaching materials. Needs analysis needs to be carried out at the beginning of the program but needs to be carried out during the language program because attitudes and learning approaches can change.

Nowadays, many kinds of research deal with the need analysis such as Maulana and Lestari (2017) and Hidayat (2018). They examined the students' need analysis in learning English. However, it can be said that English that can be taken as the object of research, Prose Studies course need, is considered an exciting thing to be conducted. Based on the characteristics of the study materials of fictional Prose, it is necessary to arrange the teaching materials in a certain way to meet students' and lecturers' needs. A learning materials meaningful verbal learning model (Elyusra \& Susyla, 2008). Also, textbooks of appreciative literature are supposed to be more relevant., according to the desire to improve students' literary appreciation (Markamah, Slamet, Rukayah, \& Minarni, 2018).

In starting lectures at the beginning of the semester, lecturers are required to prepare semester lecture plans (RPS), based on observations as well as the researcher's experience while teaching at the English Literature Study Program, Flores Ende University, the preparation of the RPS is carried out by the lecturers unilaterally without involving students. It means that the preparation of the RPS has not paid attention to the needs of students. The requirements, desires, and opinions of students have not been explored and adopted into the RPS. At the beginning of the semester, the lecturer did prepare and distributed RPS to students. In this case, the lecturer also asks students to come up with specific suggestions. However, students tend just to accept the designs that the lecturers have made.

\section{LITERATURE REVIEW}

\subsection{Need analysis}

Need analysis (also known as needs assessment). The word requires research usually applies, according to Iwai et al. (1999), to the tasks involved in obtaining knowledge that will form the basis for designing a program that will bring about the needs of a particular group of students. Analysis of needs means a process to assess the distinction between its requirements. Those are needed and those that are present. The optimal form often relates to ultimate reality, while the present one typically relates to the actual environment or circumstance.

The desired shape often refers to an ideal state, whereas the existing one usually refers to the real situation or condition. The literature outlined the value of requirements identification as an active data gathering method to define preparation support to refine the current practice to help the organization meet the mission. The creation of research conditions in the program's framework identifies learners' needs and specifies the pivotal role of updating goals. All of this is to admit that the study of needs is a method that is defined as a national education prerequisite. What is required in academic achievement is decided by this method.

\subsection{Textbook}

Textbooks are collections of knowledge based on a scientific method that embraces a widely agreed concept called an organized reading material series. Textbooks clarify the concepts and techniques of education comprehensively. Textbooks are appropriately used as guidebooks that include detailed plans, ideas, or procedures, as a universal aspect of teaching and learning programs. Therefore, to properly appreciate the lecture notes, educators and college students need to read school textbooks or other similar topics. A textbook is a research device used to sustain a teaching curriculum in schools and universities (Pingel2007). A textbook's content includes the description, text, and organizational entities, separated into segments or sections, sources, a guidebook, and a catalogue, in terms of planning.

In education, textbooks providing unique resources are used as learning guidelines. Usually, textbooks are used in combination with some other course resources, such as a worksheet, online resources for students, or software assistance (Markamah, Slamet, Rukayah, \& Minarni, 2018.

\subsection{Prose Fiction Appreciation}

Literature is an art of literary works such as novels, magazines, and books. Literature is a written production, often restricting towards those deemed to have artistic, intellectual value. Roberts and Jacob (2007) say that literature refers to a system that depicts stories, dramatizes events, shares thoughts, analyzes, and advocates ideas. There are four types or genres of writing, (1) prose fiction, (2) verse, (3) drama, and (4) prose for nonfiction. The writers choose prose fiction, precisely on a novel.

Among the literary text genres, prose fiction is a type of literary genre that is mostly available in any means of communication. With the advancement of 
technology, one can find vision easily from the internet. Many kinds of literature from different genres are downloadable from the internet, spanning from novels, short stories, mini literature, and either classic or contemporary micro-fiction. In appreciating literary works, the idea of literature for all is essential to be addressed after the oral and written knowledge gathered dealing with the international community in every place of social life always reads literary works to develop character and personality. Literature provides many opportunities to language learners, whether it is used to learn a language. In the first instance, the literature indicates cultural awareness of the people who have written the novel (Lazar, 1993). Literature may serve as a reflection of fact in the form of fiction. It represents life in the real world and the culture of society as portrayed in the document. Second, literature also offers language enrichment for learners (Floris, 2005). Learners will have multiple linguistic inputs in terms of vocabulary, grammatical form, and style. For the most part, the terminology used in literature is not a language widely used in everyday conversation and textbooks. Thus, if literature is used to teach a language, learners will learn lexical and syntactic subjects in their context. Third, literature triggers personal interaction (Floris, 2005). If the learners are directly interested in the texts they read, they will transfer their focus from the mechanical aspect of the language to the narrative's interaction (Floris, 2005), hardly conscious that they study the language. The literature will fill the study with need analysis for prose fiction appreciation from all previous explanations.

\section{METHODS}

\subsection{Research Design}

The method expended in this examination is the development process (Research and development / R \& D). Gall, Borg, and Gall (1996) stated that R\&D is a method employed for generating and developing. Based on this definition, this research rests on the efforts to developing and validating an instructional product. In this review, researchers will strive to create an academic development in the form of a curriculum, namely Analysis of Student Needs in Prose Studies course.

\subsection{Participant}

The study respondents are 23 students in English Language and Literature, Universitas Flores Faculty of Language and Literature. The participants considered for the study were done following random sampling, as no random number table and software programs were needed.

\subsection{Data Collection and Analysis}

The data were composed of 1 April until 8 May 2020 and the questionnaire as the instrument. The construction of the questionnaire was based on the conceptual framework mentioned earlier. Hutchinson and Waters (in Kaur \& Khan, 2010) developed elements of the concept of language qualifications, including the language proficiency that is considered more relevant, the study materials (general or subject-related), and the student-teacher. Furthermore, the questionnaire is in the form of a Likert-scale. A Likert scale includes a set of answers to a given question or declaration, according to Cohen (2010).

Ary, Jacobs, and Sorensen (2010) suggested that a Likert scale illustrates a collection of the subject's views and asks the respondent to pick if they agree firmly, agree, oppose, totally disagree.

In the form, the files which are achieved then will be counted by using the percentage formulation (Sugiono,2010) the following:

$$
\mathrm{P}=\mathrm{F} \times 100 \%
$$

$\mathrm{N}$

Remark: $\mathrm{P}=$ The number of percentages

$$
\begin{aligned}
& \mathrm{F}=\text { The Response frequency of respondents. } \\
& \mathrm{N}=\text { Number of Cases }
\end{aligned}
$$

Researchers perform several procedures during the survey. The processes are:

1. The researcher prepares the methods for gathering the results.

2. Administering the questionnaire. Ten questions consist of the problems in a questionnaire

3. The researcher shares the questionnaire by WAG while conducting the analysis.

4. The researcher analyses and describes it descriptively after collecting the results, drawing conclusions about the outcome of the analysis.

After gathering the information, the researcher would evaluate the information for the next step. In analysing the data, the researcher uses a descriptive qualitative approach. It is used to know student's needs on the Prose Studies course in English Literature Study Program Universitas Flores.

\section{FINDINGS AND DISCUSSION}

\subsection{Findings}

The writer presented the study outcomes and discussion as the following explanation after reviewing the questionnaire's data. Simultaneously, the questionnaire was distributed to assess the students' need for the Prose Studies course In Semester V English Literature Study Program, Universitas Flores. Two 
tables display the needs of students on the Prose Studies course.

From the table 1 below, questionnaire items 1 and 2 are used to measure learners' attitudes towards the Prose Studies course. Researchers estimate this attitude by asking questions about how important the process is to learn and the timeliness of submitting assignments. In statement one, it is clear that of the 25 respondents, nine students or $36 \%$ stated that they strongly agree on the importance of the Prose course being studied, 16 or $64 \%$ agree, and no respondents disagree and disagree. In statement number 2, there are nine students, or $36 \%$ of 25 respondents strongly agreed to collect assignments on time, 15 or $60 \%$ agreed, and one student or $4 \%$ did not agree to submit assignments on time. While in statement 3 in which describes the respondents' interest in reading literary works.

In statement three, based on the table above, it can be seen that the respondents have an interest in reading prose narrative literature. It can be seen from 9 people, or $36 \%$ of respondents strongly agree to read one of the Prose narrative literary works, 15 students or $60 \%$ agree, and one person or $4 \%$ do not agree always to read fiction. In the meantime, statements four and five describe the respondents' interest in English language skills and their attitudes if the material is integrated with these language skills. The information or questionnaire item no four above describes that 13 respondents, or $52 \%$ of 25 respondents, agreed if English language skills integrated prose material with English language skills, and 12 or $48 \%$ agreed on the integration. In statement five above, as many as 7 or $28 \%$ of 25 students strongly agree with language skills such as Reading, Listening, Speaking, and Writing. Meanwhile, 17 or $68 \%$ agree, and 1 or $4 \%$ disagree with the four language skills.

Items $6,7,8$, and 9 describe the learning methods needed by respondents in the Prose Studies course. The researcher asked questions about what respondents thought when lecturers taught using the lecture method, and their opinions were if learners were more active in learning, what teaching methods they needed when learning, what did respondents think if students in class presented group assignments. In statement six above, there is 4 or $16 \%$ of 25 respondents strongly agree on the lecture method in Prose Course learning, 2 or $8 \%$ disagree, 18 or $72 \%$ disagree, and 4 or $16 \%$ strongly disagree.

In item seven, 12 or $48 \%$ of 25 respondents strongly agree with active learners in Prose Course learning, and 13 or $52 \%$ agree on learners who are involved in the teaching. In the meantime, item eight above indicates that 13 or $52 \%$ of 25 respondents strongly agree to study in groups, and 12 or $48 \%$ choose to settle if there is group learning when looking.

In item nine above, it is clear that as many as 11 or $44 \%$ of 25 respondents agreed on the task presentation method in Prose learning, and 14 or $56 \%$ strongly agreed on that method. Besides, item 10 shows that 5 or $20 \%$ of 25 respondents like the material discipline of science and contextual prose material, 19 or $76 \%$ choose to agree, and 1 or $4 \%$ choose to disagree with the two topics.

Table 1. Students' Needs Analysis on Prose Studies Course in Semester V English Literature Study Program, Universitas Flores

\begin{tabular}{|c|c|c|c|c|c|c|c|c|c|}
\hline \multirow{3}{*}{ No } & \multirow{3}{*}{ Questionnaire Items } & \multicolumn{8}{|c|}{ Students' Responses } \\
\hline & & \multicolumn{2}{|c|}{$\begin{array}{l}\text { Strongly } \\
\text { Agree }\end{array}$} & \multicolumn{2}{|c|}{ Agree } & \multicolumn{2}{|c|}{ Disagree } & \multicolumn{2}{|c|}{$\begin{array}{l}\text { Strongly } \\
\text { Disagree }\end{array}$} \\
\hline & & Freq & $\%$ & Freq & $\%$ & Freq & $\%$ & Freq & $\%$ \\
\hline 1 & In your opinion, is a process course essential to study? & 9 & 36 & 16 & 64 & & & & \\
\hline 2 & When there is a task, you always collect it on time & 9 & 36 & 15 & 60 & 1 & 4 & & \\
\hline 3 & $\begin{array}{l}\text { Do you always read works of fiction (novels, short stories, } \\
\text { etc? }\end{array}$ & 9 & 36 & 15 & 60 & 1 & 4 & & \\
\hline 4 & $\begin{array}{l}\text { It is recommended that Prose teaching materials be } \\
\text { combined with language skills. }\end{array}$ & 13 & 52 & 12 & 48 & & & & \\
\hline 5 & $\begin{array}{l}\text { Do you like language skills such as Reading, Listening, } \\
\text { Speaking, and Writing? }\end{array}$ & 7 & 28 & 17 & 68 & 1 & 4 & & \\
\hline 6 & $\begin{array}{l}\text { What do you feel when the lecturer teaches using the } \\
\text { lecture method? }\end{array}$ & 4 & 16 & 2 & 8 & 18 & 72 & 4 & 16 \\
\hline 7 & What do you think if learners are more active in learning? & 12 & 48 & 13 & 52 & & & & \\
\hline 8 & Do you like the group learning method when studying? & 13 & 52 & 12 & 48 & & & & \\
\hline 9 & $\begin{array}{l}\text { What would be your opinion of students in class presented } \\
\text { a group assignment? }\end{array}$ & 11 & 44 & 14 & 56 & & & & \\
\hline 10 & The subject matter you like in learning prose is scientific & 5 & 20 & 19 & 76 & 1 & 4 & & \\
\hline
\end{tabular}


Table 2. The Percentage of Students' Needs Analysis on Prose Studies Course in Semester V English Literature Study Program, Universitas Flores

\begin{tabular}{|c|c|c|c|}
\hline No. & Students' Needs Criteria & Total & $\%$ \\
\hline 1 & The level of importance of the Prose course & 25 & 100 \\
\hline 2 & Timely submitting assignment & 24 & 96 \\
\hline 3 & Interest in literary works & 24 & 96 \\
\hline 4 & Students' attitude on the integration of materials and English language skills & 25 & 100 \\
\hline 5 & Interest in English language skills & 24 & 96 \\
\hline 6 & The attitude of students towards the lecture method & 6 & 24 \\
\hline 7 & The attitude of students towards learners who are active in learning & 25 & 100 \\
\hline 8 & The need for teaching method & 25 & 100 \\
\hline 9 & Students' attitude towards presentation method, independent, or group assignments & 25 & 100 \\
\hline 10 & Subjects preferred in the learning process & 24 & 96 \\
\hline
\end{tabular}

Table two above indicates the percentage of each questionnaire item. The level of importance of the Prose Studies course gets $100 \%$, timely submitting assignment $96 \%$, interest in literary works $96 \%$, students' attitude on the integration of materials and English language skills $100 \%$, interest in English language skills 96\%, the attitude of students towards the lecture method $24 \%$, the attitude of students towards learners who are active in learning $100 \%$, the need for teaching method $100 \%$, students' attitude towards presentation method, independent, or group assignments $100 \%$, and subjects preferred in the learning process get $96 \%$.

\subsection{Discussions}

The word needs often applies to preferences, desires, conditions, goals, motives, shortcomings, restrictions, and necessities (Richards, 2001). Multiple levels of situations and descriptions of specific challenges and weaknesses in applying this term, including ways in which observers can productively discriminate between the needs defined and those articulated or encountered by students (Mohammed, 2016). After researching by giving questionnaires to respondents, the student Needs in the Prose Course at the English Literature Study Program of Universitas Flores have some results. Learners' attitudes towards the Prose Studies course show that twenty-five students or $100 \%$ stated that they agreed on the importance of the Prose course being studied. Also, 24 students or $96 \%$ of the 25 respondents submitted the assignments. With an attitude of strongly agree and punctuality in collecting assignments have an impact on strong interest/motivation to learn Prose.

Prose's learning interest/motivation is evident in the data, which describes that 24 or $96 \%$ of the respondents always read one or more of Prose's narrative literary works. The frequency "always" states the condition of the habit of reading literary works, which receive a portion from the respondent. It means that of the many fiction and nonfiction reading types, literary works are still reading material for respondents. Learning of Prose can also be seen from the respondent's interest in integrating English language skills and Prose material. It is evidenced by data from 25 or $100 \%$ of 25 respondents agree if the Prose material is combined with English language skills, namely speaking, reading. listening and writing. Respondents felt that the four language skills were essential to be integrated into the learning process.

Data about the Prose learning method also shows the needs of students who prefer to learn actively. It is evidenced by as many as 25 or $100 \%$ of 25 respondents agree on active learners in the learning process. Respondents also like it if the assignment is independent/presented as many as 25 or $100 \%$ of the 25 respondents agree on the learning process's task presentation method. Also, vice versa, respondents do not like it if the lecturer always teaches the lecture method. It is evidenced by as many as 25 or $100 \%$ of the 25 respondents disagree with the lecture method in Prose learning. Furthermore, the teaching method that respondents need when studying is in groups. There is 25 or $100 \%$ of the 25 respondents who chose to study in groups. It shows that they want cooperation with their peers in the group. Subject topics preferred in the learning Process by respondents are material under scientific disciplines, contextual Prose material, material about science and technology, material about daily activities: as many as 24 people or $96 \%$ who wanted collaboration from the four topics.

\section{CONCLUSION}

This study aimed to describe the Students' Needs of Prose course in the Semester IV English Literature Study program Universitas Flores Ende. After evaluating the results, it can be concluded the Students' Needs of prose course in the Semester IV Study Program of the English Literature Study Program of the University of Flores is Prose teaching material is integrated with English Speaking, literacy, and writing skills: listening. It showed that the teaching and learning. Also, the Prose course could be combined with the four primary language skills. It is realized that learners' knowledge about it should support learning prose fiction. Books or the internet can achieve all information about fiction. Also, it is easy for learners to 
read. They can write a short story based on their real-life or what they have experienced in life. In the meantime, the teaching method that respondents need when learning Prose is in groups. It means that learners can discuss with their friends, learn many things in the group, and get much information. Also, they can share their knowledge with others. Finally, subject topics are preferred by respondents in the learning process. They are the appropriate material with scientific disciplines, contextual material, science and technology, and material about daily activities. It indicates that learners can learn the Prose course by using some other topics that can be seen or experience in our life. As a part of literature, prose fiction is universal. What happened in prose fiction stories can be happened in ours, in Indonesia, or other countries.

\section{REFERENCES}

Allo, M. D. G. (2018). An evaluative study on prose textbook (EFL curriculum and need analysis). Paper presented at The International Conference on Social Science \& Humanities 2018.

Ary, D., Jacobs, L. C., \& Sorensen, C. (2010). Introduction to research in education (8th ed). New York: Wardsworth/Thomson Learning

Cohen. (2010). Research methods in education (5th ed). London: Routledge Falmer.

Elyusra, E., \& Susyla, D.. (2018). The need of prose teaching material for instructional resources. Advances in Social Science, Education and Humanities Research, volume. Proceedings of International Conference on Language, Literature, and Education (ICLLE 2018), 64-71. https://www.atlantis-press.com/proceedings/iclle$18 / 55907950$

Floris, F. P. (2005). Using English literature written by asian authors in EFL/ESL classroom in Asia. $K @ t a, \quad 7(1), \quad 43-53$. http://kata.petra.ac.id/index.php/ing/article/view/16 268

Gall, M. D., Borg, W. R., \& Gall, J. P. (1996). Educational research: An introduction. Longman Publishing.

Hidayat, R. (2018). A need analysis in learning English for airline staff program. English Education
Journal (EEJ), 9(4), 589-613. https://jurnal.unsyiah.ac.id/EEJ/article/view/12516

Iwai, T., Kondo, K., Limm, S. J. D., Ray, E. G., Shimizu, H., \& Brown, J. D. (1999). Japanese language needs analysis. http://nflrc.hawaii.edu/NetWorks/NW13.pdf

Kaur, S., \& Khan, A. M. (2010). Language needs analysis of art and design students: Considerations for ESP course design. ESP world, 9(2), 1-16.

Lazar, G. (1993). Literature and language teaching answer guide teachers, and trainers. United Kingdom: Cambridge University Press

Markamah, E. S., Slamet, S. Y., Rukayah, R., \& Winarni, R. (2018). The development of appreciative prose textbook through active learning for students of PGSD study program in Surakarta Regions. International Journal of English Literature and Social Sciences (IJELS), 3(1), 60-65. https:/ doi.org/10.22161/ijels.3.1.11

Maulana, A., \& Lestari, F. (2017). Need analysis of English literature students in English oral communication. Journal of English Language Teaching in Indonesia, 5(2), 45-50. http://ejournal.stkipsiliwangi.ac.id/index.php/eltin/article/ view/524

Modi, M. C. B., \& Patel, D. H (2018). Exploring usefulness of needs analysis in ESL classrooms. Online Journal of Multidisciplinary Subjects, 11(4), 649-665 http://www.researchguru.net/volume/Volume\%201 1/Issue\% 204/RG79.pdf

Mohammed, S. A. H. (2016). Investigating the Application of Needs Analysis on EAP Business Administration Materials. English Language Teaching, 9(3), 74-79.

Pingel, F. (2010). UNESCO guidebook on textbook research and textbook revision. Unesco.

Richards, J. C. (2001). Curriculum development in language teaching. Cambridge: University Press.

Roberts, E. V., \& Jacobs, H. E. (2007). Literature: An introduction to reading and writing (8th ed). Pearson. 